\author{
AnNa Szosland-FAŁTyn, BEATA BARTODZIEJSKA \\ Pracownia Mikrobiologii \\ Zakład Jakości Żywności \\ Instytut Biotechnologii Przemysłu Rolno-Spożywczego im. prof. W. Dabrowskiego \\ Piłsudskiego 84, 92-202 Łódź \\ E-mail: anna.szosland@ibprs.pl
}

\title{
CAMPYLOBACTER JEJUNI KAMELEON WŚRÓD BAKTERII - FORMY MORFOLOGICZNE ORAZ ICH PATOGENNOŚĆ*
}

\section{WPROWADZENIE}

Kształt komórek bakteryjnych jest jedna $z$ podstawowych (obok budowy ściany komórkowej, przetrwalników czy zdolności ruchu) cech morfologicznych umożliwiajacych ich identyfikację. Również nazewnictwo bakterii opiera się na kształcie komórek zaobserwowanym pod mikroskopem. Tymczasem, dzięki mikroskopii elektronowej wykazano, $\dot{z}$ e nie jest to cecha stała mikroorganizmów. Transformacja pałeczek bakteryjnych $\mathrm{w}$ formy sferyczne, ziarniakowate lub kokoidalne (ang. coccoid form, CF) jest właściwością coraz częściej potwierdzaną wśród drobnoustrojów Gram-ujemnych. Proces ten inicjowany jest stresowymi dla bakterii warunkami, np. niedoborem substancji odżywczych, podwyższona temperatura lub obecnościa substancji toksycznych. Występowanie postaci $C F$ związane jest ściśle $z$ druga forma morfologiczna bakterii, żywa, lecz nie dająca się hodować (ang. viable but non culturable, VBNC). Istnienie wspomnianych stanów wykazano m.in. dla takich drobnoustrojów jak: Salmonella Typhimurium, Pseudomonas aeruginosa, Vibrio vulnificus, Vibrio cholerae, Mycobacterium smegmatis, Mycobacterium tuberculosis, Helicobacter pylori oraz dla szerzej omawianego w artykule gatunku Campylobacter jejuni (KREBS i TAYLOR 2011, OLSZEWSKA i ŁANIEWSKATROKENHEIM 2013, MOGHOOFEI i współaut. 2015). Odkrycie odrębnych morfologicznie form zapoczątkowało dyskusję na temat nie tylko stanu fizjologicznego i aktywności metabolicznej, ale również potencjalnej patogenności. Pałeczki C. jejuni sa obecnie jednym $z$ najczęstszych czynników etiologicznych zaburzeń żoładkowo-jelitowych u ludzi. Szeroko rozprzestrzenione w przyrodzie, wykrywane w produktach pochodzenia zwierzęcego oraz w zanieczyszczonej wodzie pitnej, moga doprowadzić do zakażenia człowieka, które $\mathrm{w}$ ostrym przebiegu określane jest jako kampylobakterioza (PIETRZAK 2010). Czynnikami odpowiedzialnym za wirulencję pałeczek $C$. jejuni są między inymi: zdolności ruchu, czynniki adhezyjne (CadF, JlpA, PEB1, MOMP, CapA, FlaC, FspA), zdolność do chemotaksji i energotaksji, obecność lipooligosacharydu i otoczki polisacharydowej, wytwarzanie toksyn i białek sekrecyjnych, obecność plazmidu czy też zmienność genetyczna (FRIRDICH i współaut. 2012, MELO i współaut. 2013, RoKOSZ-CHUDZIAK i RASTAWICKI 2014, KoOLMAN i współaut. 2016). Ze względu na nie w pełni wyjaśniony mechanizm chorobotwórczości C. jejuni sugeruje się, że odmienne stadia rozwoju moga również odgrywać istotna rolę $\mathrm{w}$ przeżyciu i rozprzestrzenianiu się tego patogenu $\mathrm{w}$ środowisku, jak również w wirulencji. Celem artykułu jest przedstawienie aktualnego stanu wiedzy na temat morfologicznych form C. jejuni i czynników stymulujących ich powstanie, a także ich znaczenia w patogenności tej pałeczki. 
FORMY PAŁECZKOWATE C. JEJUNI I ICH MECHANIZM PATOGENNOSCI

W badaniu mikroskopowym C. jejuni jest Gram-ujemna, helikalna pałeczką o zagiętym kształcie, długości do 5,0 $\mu \mathrm{m}$ i szerokości do $0,8 \mu \mathrm{m}$, nie tworząca spor. Jest termofilnym, mikroaerofilnym i kapnofilnym gatunkiem wymagajacym do wzrostu atmosfery o zwiększonej zawartości dwutlenku węgla. Wykazuje ruch korkociagowy. Jest to możliwe dzięki obecności pojedynczej rzęski, zbudowanej z ciałka podstawowego, haka i filamentu, umieszczonej na jednym, bądź na obu biegunach komórki (SILVA i wpółaut. 2011, FRIRDICH i współaut. 2012, EPPS i współaut. 2013, BOLTON 2015, JOSEFSEN i współaut. 2015). Filament rzęski składa się $z$ dwóch homologicznych białek FlaA i FlaB (z przewaga tego pierwszego), kodowanych przez dwa geny, odpowiednio flaA i flaB. Wyłaczenie obu genów powoduje powstanie nieruchliwych mutantów pałeczek C. jejuni, przez co obniża się ich zdolność do kolonizacji i inwazji śluzówki jelita (MElo i wpólaut. 2013, ROKOSZ-CHUDZIAK i RASTAWICKI 2014). Pałeczki C. jejuni cechuje ponadto obecność białka CadF (ang. Campylobacter adhesion to fibronectin) o masie $37 \mathrm{kDa}$. Białko CadF odgrywa istotna role $\mathrm{w}$ patogenezie zakażenia, łącząc się $z$ fibronektyna enterocytów nabłonka jelit, i umożliwiajacc $\mathrm{w}$ ten sposób adherencję bakterii do komórek nabłonka. Mutanty $C$. jejuni nieprodukujace białka CadF nie maja zdolności do kolonizacji komórek nabłonkowych (ROKOSZ-CHUDZIAK i RASTAWICKI 2014). Kolejnym $\mathrm{z}$ mechanizmów wirulencji pałeczek C. jejuni jest zdolność produkcji toksyn. Najlepiej poznana $z$ nich jest cytoletalna genotoksyna (ang. cytolethal distending toxin, CDT), kodowana przez trzy geny: cdtA i cdtB cdtC. Mechanizm działania tej toksyny polega na uszkodzeniu materiału genetycznego komórek eukariotycznych, zatrzymania ich cyklu komórkowego i śmierci. Dla zachowania pełnej aktywności przez toksynę CDT konieczna jest obecność trzech podjednostek genowych (LAI i współaut. 2016).

W odpowiedzi na stres wywołany głodem, zbyt wysoka lub niska temperatura, hiperosmolarnościa, niskim $\mathrm{pH}$, obecnościa tlenu, formy pałeczkowate (ang. rod form, $\mathrm{RF})$ C. jejuni przechodza zmiany morfologiczne i metaboliczne, prowadzace do ekspresji ściśle określonych genów, regulowanych na poziomie transkrypcji i translacji. Do najczęściej wymienianych w literaturze genów, których produkty uczestnicza w odpowiedzi komórki na stres należą: spoT, fliA, rpoD i
rpoN, htrA. Białko SpoT, produkt genu spoT uczestniczy $\mathrm{w}$ degradacji nukleotydu czterofosforanu guanozynowego (ppGpp) w reakcji pirofosforolizy. ppGpp jest czasteczka sygnałowa, generowana pod wpływem zmian środowiskowych. Dzięki niej w komórce bakteryjnej następuje ograniczenie wielu aktywności metabolicznych, co określa się mianem odpowiedzi ścisłej. Za inicjację transkrypcji genów odpowiedzialne sa alternatywne czynniki sigma, które $\mathrm{w}$ kompleksie $\mathrm{z}$ rdzeniem polimerazy RNA reguluja ten proces. Do alternatywnych czynników sigma charakterystycznych dla $C$. jejuni należą trzy: FliA (sigma28), RpoD (sigma54), RpoN (sigma 54). Czynniki te sa kodowane odpowiednio przez geny fliA, rpoD i rpoN $i$ odpowiedzialne sa między innymi za biosyntezę flageliny, ruchliwość, wydzielanie białek i inwazyjność (NIEROP GROOT i wpółaut. 2014).

\section{FORMY KOKOIDALNE}

Poczatkowo przyjmowano, iż jedyna forma morfologiczna C. jejuni jest postać pałeczkowata. Jednak w 1962 r. ukazały sie publikacje na temat form kokoidalnych występujących u bakterii Campylobacter spp. Dotyczyły one innego gatunku, Vibrio fetus, który w 1994 r. został zaklasyfikowany do rodziny Campylobacteraceae (OGG 1962). W 1993 r. Griffiths wykazał, że transformacja komórek C. jejuni zależna jest od faz wzrostu. Formy pałeczkowate charakterystyczne sa dla fazy logarytmicznego wzrostu, zaś postaci CF dla fazy stacjonarnej. Dalsze badania wykazały, że formy kokoidalne, pomimo obecności rzęsek, pozbawione sa ruchu. Będąc w stanie uśpienia, wykazuja deficyt energii potrzebnej do rotacji wici, pochodzacej $z$ gradientu protonów $\mathrm{w}$ poprzek wewnętrznej błony cytoplazmatycznej (MOORE 2001). Mikroskopia elektronowa wykazała odmienną wielkość komórek kokoidalnych od form pałeczkowatych oraz różnice $\mathrm{w}$ budowie ściany komórkowej, co potwierdziło także barwienie Grama. Komórki w formie CF nie były zdolne zatrzymać odpowiedniej ilości fuksyny czy safraniny. W porównaniu do form pałeczkowatych, komórki kokoidalne charakteryzowały się niższą zawartością kwasów nukleinowych i polipeptydów, takich jak dysmutaza ponadtlenkowa. Ponadto, zawierały mniej peptydoglikanu, który w trakcie przechodzenia komórek w stadium kokoidalne ulegał częściowej degradacji. Podejrzewa się, że pewną rolę w przemianie do formy kokoidalnej moga odgrywać następujace białka:

- AmiA amidaza N-acetyl-muramyl-L-alaninowa (amidaza N-MurAc- L-Ala), enzym $z$ grupy hydrolaz hydrolizujacy peptydoglikan; 
- PBP 2 uczestniczace w syntezie mureiny, tworzącej cylindryczną część komórki tzw. mureinę elongacyjna;

- RodA regulujace aktywność PBP 2 i wraz $z$ nim tworzace kompleks syntetazy peptydoglikanu;

- MreB aktynopodobne białko stabilizujące kształt komórki, nadajace jej sztywność oraz odpowiedzialne za utrzymanie stałej szerokości komórki.

Pomimo stwierdzenia obecności w genomie C. jejuni genów amiA, mreB, pbp2 i $\operatorname{rod} A$ kodujacych te białka, ich rola w powstawaniu form $\mathrm{CF}$ nie jest jednak w pełni wyjaśniona (CHAPUT i współaut. 2006). Nadal ukazuja się sprzeczne informacje co do żywotności form kokoidalnych.

\section{FORMY VBNC}

Pierwsze wzmianki na temat istnienia stadium VBNC bakterii pojawiły się w latach 89. XX w. Od tego momentu wykrywa się coraz więcej drobnoustrojów mających tę zdolność, wraz $z$ czynnikami stymulujacymi przechodzenie $w$ ten stan. Stadium VBNC komórek cechuje brak zdolności wzrostu na znanych klasycznych pożywkach hodowlanych, a indukowane jest, podobnie jak przy przechodzeniu w formy CF, niesprzyjajacymi warunkami środowiska (OLSZEWSKA i ŁANIEWSKATROKENHEIM 2013, ADAMIAK i współaut. 2015). Pałeczki wchodzace w stan VBNC podlegaja morfologicznym, fizjologicznym i genetycznym przemianom, które pozwalaja im przetrwać w niesprzyjajacym środowisku przez dłuższy czas, zachowując zdolność infekcji. Przemiany te sa odwracalne. W stanie VBNC komórki wydłużaja się lub przechodzą w formę kulista, moga zmniejszać swoją objętość od 15 do 300 razy. Następuje stabilizacja ściany i błony komórkowej, wzrost gęstości cytoplazmy, poprzez zmniejszenie ilości lipidów i białek, spadek zawartości kwasów nukleinowych i rybosomów. W składzie błon komórkowych form VBNC pojawiaja się białka indukowane stresem, m.in. białka szoku cieplnego należące do grupy Hsp (ang. heat shock protein), białka głodowe (ang. starvation proteins), w wyniku czego powstałe formy wykazuja zdecydowanie większa oporność na niekorzystne warunki. W celu podtrzymania potencjału membranowego obserwuje się też obniżenie transportu aktywnego i aktywności respiracyjnej. Komórki C. jejuni w stanie VBNC charakteryzuja się wirulencja oraz adherencja do różnego typu powierzchni abiotycznych. Moga wchodzić w skład biofilmu znacznie oporniejszego na biocydy niż komórki planktoniczne.
W doświadczeniach PATRONE i współaut. (2013) przez trzy tygodnie obserwowano w formach VBNC C. jejuni wysoki poziom ekspresji genu cadF. Ponadto, bakterie w stadium VBNC były zdolne w warunkach in vitro przylegać do komórek nabłonka jelitowego linii komórkowej Caco-2. Należy jednak podkreślić, że zdolność powrotu ze stanu VBNC do formy wegetatywnej zależy od stopnia intensywności zmian postępujacych w komórce oraz od długości okresu przebywania w takiej postaci, gdyż przekroczenie pewnej granicy może doprowadzić do rozpadu komórki zamiast do jej reaktywacji. Właściwość ta jest jednak bardzo indywidualna i zależna od rodzaju drobnoustroju, a nawet szczepu.

\section{CZYNNIKI STYYMULUJACE INDUKCJE INNYCH NIŻ PAŁECZKOWATE FORM C. JEJUNI}

Wśród warunków mogacych wpływać na indukcję innych niż RF stanów C. jejuni należy wymienić przede wszystkim stres temperaturowy, stres oksydacyjny, niedobór substancji odżywczych, obecność substancji toksycznych i programowana śmierć komórki - apoptoze (KONOPELSKI i DYNOWSKA 2014). Potwierdzaja to badania KLANČNI i współaut. (2009). Wynika $z$ nich, że w trakcie długiego czasu inkubacji C. jejuni wynoszacego 42 dni, w warunkach głodowych $80 \%$ komórek bakteryjnych uległo transformacji do form kokoidalnych. Jednocześnie, w hodowli stwierdzano obecność form VBNC co sugeruje, że jest to zupełnie odmienne stadium niż CF. HE i CHEN (2010), hodując przez tydzień C. jejuni w warunkach stresowych (w atmosferze tlenowej, temperaturze $25^{\circ} \mathrm{C}$ i w podłożu ubogim pod względem składników odżywczych), otrzymali 99\% komórek w formie kokoidalnej, lecz nie dającej się wyhodować. W doświadczeniach OH i współaut. (2015), z użyciem mikroskopu fluorescencyjnego dowiedziono, że w warunkach stresu oksydacyjnego, trwającego dwanaście godzin, 49\% populacji C. jejuni przyjmowało postać kokoidalna, podczas gdy w warunkach mikroaerofilnych formy te stanowily zaledwie ok. 3\%. CHAISOWWONG i współaut. (2012), inkubujac przez 38 dni w temperaturze $4{ }^{\circ} \mathrm{C}$ bakterie C. jejuni otrzymali, barwiąc fluorescencyjnie zestawem Baclight, 70\% żywych, lecz nie dajacych się hodować bakterii. Naukowcy potwierdzili, że stres zimna indukuje powstanie form VBNC, w których dochodzi do ekspresji genów odpowiedzialnych za wirulencję tj. flaA, flaB, cadF, ciaB, cdtA, cdtB i $c d x c$, co stanowi poważne zagrożenie dla zdrowia publicznego. 


\section{PODSUMOWANIE}

Znalezienie odpowiedzi na pytania, czy istnienie innych form niż pałeczki $C$. jeju$n i$ jest sposobem na przetrwanie tej bakterii poza organizmem gospodarza, jakie inne czynniki stymuluja przekształcanie do postaci CF i VBNC oraz wyjaśnienie mechanizmu transformacji, może być podstawa zrozumienia chorobotwórczości tej bakterii oraz opracowania skutecznych metod jej inaktywacji.

$$
\text { Streszczenie }
$$

Pałeczki Campylobacter jejuni sa obecnie jednym $z$ najczęstszych czynników etiologicznych zaburzeń żołąkowo- jelitowych u ludzi. Szeroko rozprzestrzenione w przyrodzie, wykrywane w produktach pochodzenia zwierzęcego oraz w zanieczyszczonej wodzie pitnej, moga doprowadzić do zakażenia człowieka, które w ostrym przebiegu określane jest jako kampylobakterioza. Wyniki badań przemawiaja za tym, że w przeżyciu i ekspansji tego patogenu $\mathrm{w}$ środowisku, jak również $\mathrm{w}$ wirulencji, istotną rolę mogą odgrywać odmienne morfologicznie stadia komórkowe C. jejuni. Celem artykułu jest przedstawienie aktualnego stanu wiedzy na temat transformacji pałeczek C. jejuni do innych form oraz czynników stymulujacych te procesy, a także ich znaczenia $\mathrm{w}$ patogenności tej bakterii.

\section{LITERATURA}

ADAMiaK J., OTLEWSKA A., GutAROWSKA B., 2015. Współczesne metody stosowane $w$ analizie biodeterioracji obiektów zabytkowych. Kosmos 64, 57-69.

BOLTON D. J., 2015. Campylobacter virulence and survival factors. Food Microbiol. 48, 99-108.

Chaisowwong W., Kusumoto A., Hashimoto M., HARADA T., MAKLON K., KAWAMOTO K., 2012. Physiological characterization of Campylobacter jejuni under cold stresses conditions: its potential for public threat. J. Vet. Med. Sci. 74, 43-50.

Chaput C., Ecobichon C., Cayet N., Girardin S. E., Werts C., Guadagnini S, Prévost M.-C., Mengin-LeCReulX D., Labigne A., Boneca I. G., 2006. Role of AmiA in the morphological transition of Helicobacter pylori and in immune escape. PLoS Pathog. 2, 97.

EpPS S. V. R., HARVEY R. B., Hume M. E., PHILLIPS T. D., ANDERSON R. C., NisBeT D. J., 2013. Foodborne Campylobacter: infections, metabolism, pathogenesis and reservoirs. Int. J. Environ. Res. Publ. Health 10, 6292-6304.

FRIRDICH E., BIBOY J., ADAMS C., LEE J., ELLERMEIER J., GIELDA L. D., DIRITA V. J., GIRARDin S. E., Vollmer W., GaYno E. C., 2012. Peptidoglycan-modifying enzyme Pgpi is required for helical cell shape and pathogenicity traits in Campylobacter jejuni. PLoS Pathog. 8, 1002602 .

HE Y., CHEN C.-Y., 2010. Quantitative analysis of viable, stressed and dead cells of Campylobacter jejuni strain 81-176. Food Microbiol. $27,439-446$.

Josefsen M. H., Bhunia A. K., Engvall O. E., FACHMANN M. S. R., HOORFAR J., 2015. Monitoring Campylobacter in the poultry production chain- from culture to genes and beyond. J. Microbiol. Meth. 112, 118-125.
KLANČNI A., GUZEJ B., JAMNIK P., VUČKOVIĆ D., ABRAM M., SMOlE MoŽINA S., 2009. Stress response and pathogenic potential of Campylobacter jejuni cells exposed to starvation. Res Microbiol. 160, 345-352.

KONOPELSKI P., DYNOWSKA A., 2014. Programowana śmierć komórki a biakka $z$ rodziny inhibitorów apoptozy (IAP) $i$ ich rola $w$ nowotworzeniu. Kosmos 63, 1-12.

Koolman L., Whyte P., Burgess C., Bolton D., 2016. Virulence gene expression, adhesion and invasion of Campylobacter jejuni exposed to oxidative stress (H2O2). Inter. J. Food Microbiol. 220, 33-38.

KREBS S. J., TAYLOR R. K., 2011. Nutrient-dependent, rapid transition of Vibrio cholera to coccoid morphology and expression of the toxin co-regulated pilus in this form. Microbiol. 157, 2942-2953.

LAI C. K., CHEN Y. A., LIN C. J., LiN H. J. KaO M. C., Huang M. Z., Lin Y. H., Chiang-Ni C., Chen C. J., Lo U. G., LiN L. C., LiN H., HsieH J. T., LAI C. H., 2016. Molecular mechanisms and potential clinical applications of Campylobacter jejuni cytolethal distending toxin. Front. Cell. Infect. Microbiol., doi: 10.3389/ fcimb.2016.00009.

Melo R. T., Nalevaiko P. C., Mendonça E. P., Borges L. W., Fonseca B. B., Beletti M. E., Rossi D. A., 2013. Campylobacter jejuni strains isolated from chicken meat har bour several virulence factors and represent a potential risk to humans. Food Control. 33, 227-231.

Moghoofei M., FAZEl H., POURSina F., EsfaHANi B. N., MOghim S., VAEZ H., HADIFAR S., SAFAEI H. G., 2015. Morphological and bactericidal effects of amikacin, meropenem and imipenem on Pseudomonas aeruginosa. Jundishapur J. Microbiol. 8, 1-5.

MoORE J. E., 2001. Bacterial dormancy in Campylobacter: abstract theory or cause for concern? Int. J. Food Sci. Technol. 36, 593-600.

NieroP GRoOT M. N., DE BOER A. G., VAN PELT W., Van Der Hulst-Van Arkel M. C., De LeEUW P., WidJaja H. C., SMiTS M. A., VAN DER WAL F. J., 2014. A SpoT polymorphism correlates with chill stress survival and is prevalent in clinical isolates of Campylobacter jejuni. Poult. Sci. 93, 2900-2909.

OGG J. E., 1962. Studies on the coccoid form of ovine Vibrio fetus I. Cultural and serologic investigations. Am. J. Vet. Res. 23, 354-358.

$\mathrm{OH}$ E., Mcmullen L., BYeOnghwa J., 2015. Impact of oxidative stress defense on bacterial survival and morphological change in Campylobacter jejuni under aerobic conditions. Front. Microbiol. 6, 1-8.

OlSZEWSKA M., ŁANIEWSKA-TROKENHEIM Ł., 2013. Odpowiedź bakterii fermentacji mlekowej na stres - stadium VBNC. Żyw. Nauk. Technol. Jak. 5, 15-28.

PATRONE V., CAMPANA R., VALLORANI L., DOMINICI S., FEDERICI S., CASADEI L., GiOACCHINI A. M., STOCCHI V. BAFFONE W., 2013. CadF expression in Campylobacter jejuni strains incubated under low-temperature water microcosm conditions which induce the viable but non-culturable (VBNC) state. Anton. Leeuw. 103, 979988.

PIETRZAK D., 2010. Perspektywy stosowania wysokich ciśnień $w$ produkcji żywności wygodnej $z$ miesa drobiowego. Żyw. Nauk. Technol. Jak. 2, 16-28.

ROKOSZ-CHUDZIAK N., RASTAWICKI W., 2014. Wybrane mechanizmy chorobotwórczości pałeczek 
Campylobacter jejuni. Med. Dośw. Mikrob. 66, 47-58.

Silva J., Leite D., Fernandes M., Mena C., GibBs

P. A., TEIXEIRA P., 2011. Campylobacter spp. as a foodborne pathogen: A review. Front. Microbiol. 2, 1-12.

\title{
KOSMOS Vol. 67, 3, 591-595, 2018
}

\author{
AnNa Szosland-FAŁTyn, BEATA BARTODZIEJSKA
}

Laboratory of Microbiology, Department of Food Quality, Pilsudskiego 84, 92-202, Lodz, Poland, E-mail: anna.szosland@ibprs.pl

\section{CAMPYLOBACTER JEJUNI A CHAMELEON AMONG BACTERIA - MORPHOLOGICAL FORMS AND THEIR PATHOGENICITY}

\section{Summary}

The rods of Campylobacter jejuni are currently regarded as one of the most common etiologic agents of gastrointestinal disorders in humans. Widespread occurrence in nature, presence in contaminated animal products, and in drinking water can lead to human infection, which in the acute form is called as campylobacteriosis. Results of studies suggest, that distinct morphological stages of the $C$. jejuni cells may play an important role in the expansion and survival of the pathogen in the environment, as well as for their virulence. The aim of this paper is to present the current state of knowledge on the transformation of $C$. jejuni into other forms and factors that stimulate these processes, and also their significance for the pathogenicity of the bacteria.

Key words: Campylobacter jejuni, morphological forms, pathogen 